\title{
Changes in the Beliefs of the Prospective Teachers on Knowledge, Learning and Teaching in a Social Constructivist Teaching Setting Applied
}

\section{Sosyal Yapılandırmacılık Öğretme Setinin Uygulandığı Öğretmen Adaylarının Bilgi, Öğrenme ve Öğretmeyle İIgili İnançlarında Değişiklikler}

\author{
Servet DEMİR ${ }^{\mathbf{1}}$ \\ Gaziantep Üniversitesi \\ Erdal BAY ${ }^{2}$ \\ Gaziantep Üniversitesi \\ Birsen BAGCECI ${ }^{3}$ \\ Gaziantep Üniversitesi \\ Ömer Faruk VURAL ${ }^{4}$ \\ Gaziantep Üniversitesi \\ Müjdat AVCI ${ }^{\mathbf{5}}$ \\ Aksaray Üniversitesi
}

\begin{abstract}
Epistemological beliefs are the individuals' point of view on what is knowledge, how to accumulate it, defining its boundaries and identifying the criteria. This study aims to investigate whether there is a change in the beliefs of the prospective teachers related to knowledge, learning and teaching in a social constructive teaching setting. The research has been conducted with 119 prospective teachers. This study is a semi-experimental one conducted with pretest and post-test without a control group. Data has been collected with 'Epistemological Belief on Learning and Teaching' scale developed by Ching Sing Chai, Timothy Teo and Chwee Beng Lee. The findings indicated a positive change in the beliefs of the candidates about relative knowledge and a visible decrease in the beliefs about absolute knowledge. Also, learning environment significantly affected the beliefs of the prospective teachers about relative knowledge. The results have proven that there occurred changes on the beliefs of prospective teachers' knowledge, learning and teaching.
\end{abstract}

Key words: Epistemological belief, Social constructive, Knowledge, Learning, Teaching

\footnotetext{
1 Doç. Dr., Gaziantep Üniversitesi, Eğitim Fakültesi, e-mail: demirservet@gmail.com

2 Doç. Dr., Gaziantep Üniversitesi, Eğitim Fakültesi, e-mail: erdalbay@hotmail.com

3 Doç. Dr., Gaziantep Üniversitesi, Eğitim Fakültesi, e-mail: bagceci@gantep.edu.tr

${ }^{4}$ Doç. Dr., Gaziantep Üniversitesi, Eğitim Fakültesi, e-mail: ofarukvural@gmail.com

${ }^{5}$ Doç. Dr., Aksaray Üniversitesi, Fen Edebiyat Fakültesi, e-mail:

mujdatavci@aksaray.edu.tr
} 


\section{Özet}

Epistomolojik inançlar, bilgi nedir, nasıl oluşturulur ile ilgili bireylerin görüşleri, sınırlarının tanımlanması ve kriterlerinin belirlenmesidir. Bu çalışmanın amacı öğretmen adaylarının sosyal yapılandırmacı öğretim seti içinde bilgi, öğrenme ve öğretme inançlarına yönelik değişimlerin incelenmesidir. Çalışma 119 öğretmen adayı üzerinde uygulanmıştır. Bu çalışma, kontrol grubu olmadan ön test ve son test ile yapılan yarı deneysel bir çalışmadır. Veriler, Chai, Teo ve Lee (2009) tarafından geliştirilen "Öğrenme ve öğretme üzerine epistomolojik inançlar ölçeği" kullanılarak toplanmıştır. Bulgular, çalışmaya katılanların göreceli bilgileri üzerindeki inançları üzerinde pozitif yönde değişimin olduğunu ve mutlak bilgiye dair inançlarında görülür derecede azalma olduğunu göstermiştir. Ayrıca, öğrenme ortamlarının katılımcıların göreceli bilgilerle ilgili inançları üzerinde anlamlı etkisi olmuştur. Sonuçlar, öğretmen adaylarının bilgi, öğrenme ve öğretme inançlarında değişiklikler meydana geldiğini kanıtlamıştır.

Anahtar kelimeler: Epistomolojik inançlar, Sosyal yapılandırmaclık, Bilgi, Öğrenme, Öğretme

\section{Introduction}

There are several factors affecting teachers' practices in the classroom such as their experiences, teaching fields, philosophy and approaches to change. Moreover, their beliefs also have an impact on their classroom practices (Levin \& Wadmany, 2005). Although "belief" has not been defined exactly, according to Pajares (1992) educational researchers define it in their own way. Deryakulu (2004) stated that every individual evaluates the situations that they encounter with from their own perspectives and interprets them. Beliefs emerge when individuals accept these interpretations as the truth. Belief is connected to knowledge that is the production of individual processes (Otting, Zwaal, Tempelaar, \& Gijselaers, 2010). The relation between the knowledge and the belief leads the researchers to the "epistemological belief" that is the natural production of individual process (Brownlee, Purdie, \& Boulton-Lewis, 2001; Hofer \& Pintrich, 1997; Ravindran, Greene, \& Debacker, 2005). Epistemological beliefs are regarded as individuals' point of view on what is knowledge, how to accumulate it, defining its boundaries and criteria (Perry, 1981). Studies on the individuals' epistemological beliefs are based on Perry's research (1970) in the first place (Brownlee, 2001).

According to the relevant research that has been conducted so far, it can be concluded that epistemological beliefs have a distinguishing impact on the variables such as the way individuals process and interpret the new knowledge, comprehension level and the criteria determined, learning strategies, cognition and approach to problem solving, effort and time they spend on learning (Aksan, 2006; Tolhurst, 2007).

In this respect, the research has shown that epistemological beliefs have some sub-dimensions as follows a) knowledge (Joanne Brownlee et al., 2001; Schommer \& Dunnell, 1997; Young, 2000), b) learning (Joanne Brownlee et al., 2001; Schommer \& Dunnell, 1997; Young, 2000), c) teaching (Joanne Brownlee 
et al., 2001; Schommer \& Dunnell, 1997; Young, 2000). When we have a look at these sub-dimensions, according to Hofer (2002) epistemology is regarded as the method to gather the knowledge, nature of the knowledge, accessibility and the accuracy while in educational respect it deals with how to generate and enhance the knowledge. Schommer (1990) suggested that in the process of generating the knowledge, individuals take the knowledge as either absolute (certain) or relative (contextual). Some claimed that absolute knowledge is an unchanged and certain knowledge reported by experts (Chan \& Elliott, 2002) and relative knowledge is an uncertain, tentative and contextual knowledge that the experts do not know everything (Hofer \& Pintrich, 1997; Schommer, 1990).

When we look at the beliefs of the individuals for "learning" which is another sub-dimension of epistemological beliefs, learning is affected by the effort, ability and the duration (Chai, Teo \& Lee, 2009; Zhu, Valcke \& Schellens, 2008). There are many learning theories trying to explain relationship between students' learning, effort expended by students, ability students have and duration required by students to learn new information (Clarebout, Elen, Luyten \& Bamps, 2010; Tumkaya, 2012).

The results obtained from a research which was conducted in Hong Kong have shown that as the prospective teachers believe more in absoluteness of the knowledge, they also regard that ability is more significant in learning process (Chan \& Elliott, 2000). On the other hand, in some research it is suggested that people believe more in the necessity of duration and effort for learning (Schommer-Aikins, Mau, Brookhart, \& Hutter, 2000; Schreiber \& Shinn, 2003). According to Tumkaya (2012) study, there are no meaningful difference in the belief concerning that "learning depends on effort; learning depends on ability; and learning depends on duration" according to academic success levels of the students. Aypay (2011) has also concluded that prospective teachers' question is the source of knowledge and they think the effects of the granted abilities are less significant and correspondingly effort and duration has respectively higher impact in learning.

Individuals' beliefs in "teaching" as another sub dimension are identified under two categories as follows; the conveyance of the knowledge in a direct way (traditional approach) and the process of knowledge apprehension (constructivist approach) (Chai et al., 2009). In the first category, teaching as a process of knowledge transmission. While the teachers incline towards instructive teaching of subject matter, the students have the role of passive learners. In the second category, teaching as a process of constructing knowledge. While the teachers facilitate the process of learning, the students play in a main role by efforting to make sense of their experiences (Brooks, 2002; Chai et al., 2009). Individuals who carry a constructivist epistemology evaluate the knowledge during the process and recreate it in their own way instead of accommodating themselves to the absolute knowledge and use it in a passive participation that is appropriate for their abilities. The teachers who believe that knowledge is practical and learning ability is inherent tend to prefer more didactiable teaching practices in nature (Chai et al., 2009). Because those who adopt the constructivist approach internalize the knowledge in this process 
instead of granting the absolute knowledge that has been advocated by the traditional approach, individuals create their own perspectives and assume that there are several ways to reach the truth (Buehl, 2003). Constructivist-oriented teachers believe that knowledge is constructed and learning ability is changeable. They believe teaching as supporting knowledge-building process and revising beliefs (Chai et al., 2009). According some research reports (Minor, Onwuegbuzie, Witcher, \& James, 2002), the pre-service teachers endorsed both traditional and constructivist approach of teaching. Entwistle and colleagues (2000) reported that teachers in their early years of profession do not likely fascinate to use both traditional and constructivist approaches in their teaching.

\section{Research Questions}

The main purpose of this research is to focus on the change on the beliefs about information, learning and teaching of the per-service teachers in social-constructivist learning environment. Throughout this purpose, an answer has been thought for the questions below:

According to the pre-test and post-test results of the pre-service teachers in social-constructivist settings:

1- Has there been any change on their beliefs about information?

2- Has there been any change on their beliefs about learning?

3- Has there been any change on their beliefs about teaching?

\section{Research Design}

\section{Method}

In this research the pre-test, post-test control and semi-experimental pattern has been used. The two experiment groups have been used to gather the data from beginning to end of the study. The control group hasn't been used in this study. The traditional method is commonly used in such studies and it's hoped that one of the researchers uses the traditional method in his own group. However, it seems impossible for the researchers to acquire the recent up-todate constructivist approach because their epistemological beliefs after them to turn their learning processes into real life.

\section{Subjects}

The research has been made on the participants who are being lectured in 'Teaching principles and methods' course at University in Turkey, Faculty of Education in 2010-2011 academic year. During the research, the researchers carried out their learning processes in two different classes. The group of the first researcher was dubbed as 'experiment one' and for the second researcher 'experiment two'. There were 81 prospective teachers in experiment one while there were 38 prospective teachers in experiment two. The experiment was conducted on the two groups to improve the reliability and validity of the study. 


\section{Transactions applied on experiment groups}

Some applications based on social constructivist approach were carried out on experiment groups during the research process that can be seen in the Table 1 below.

Table 1. Research Context of Experimental Group

\begin{tabular}{ll}
\hline Approach & -Social Constructivist \\
\hline Teacher Role & -Scaffold \\
& -Planning \\
& -Procedural \\
& -Motivation \\
& -Acquiring higher order skills \\
Role Of Learner & -Autonomous learner \\
& -Social learner \\
Learning Environment & -Active learner (reflector, creative, critical) \\
& -Authentic task \\
& -Collaborative environment \\
& -Democratic environment \\
& -Constructivist environment \\
& -Having a goal \\
& -Authentic task \\
Evaluation & -Alternative evaluation \\
& -Formative evaluation \\
& -Portfolio \\
& -Peer \& self-evaluation \\
\hline
\end{tabular}

In the study, the researchers as teachers organized the learning process that is appropriate for social constructivist approach to learning. As Jonassen (1999) stated, the constructivist learning environment was designed to be constructive, purposeful, interactive, collaborative, reflective, providing high level learning, and complex for the students. Intensive learning environment, which consists of dialogue, research, problem solving and social interaction were provided for the students. The researchers in the role of teacher showed high level procedural roles such as planning and motivation which promote learning. It was paid attention to make the students social, independent and active learners.

The throughout research process, first of all, the researchers informed about the learning process and planned the learning process activities (planning the learning process with students). Then, the views of the students about the learning process were taken, and they were motivated about the issues that they were concerned about. For example; the process that appears to be particularly complex and difficult at the beginning can be easily managed by them. Verbal persuasion and previous examples were demonstrated to support that they can learn thoroughly in the process (realizing that motivation and learning is a process). The students were asked to identify the group of friends 
they want to work together until the end of the term. They set groups of 4-5 students (learning autonomy) on their own. Authentic tasks that groups perform were defined and performance guidelines and forms related to the authentic tasks were shared with the students. Within the context of authentic tasks, the students prepared the plans according the goals and methods assigned to them during the course, and they implemented these plans in the courses of a real school environment after receiving permission. All of the process was recorded with the camera during the implementation process. The obtained products shared during the course by the students were evaluated on the basis of authentic and complementary assessment methods and approaches.

Throughout the lectures there has never been a special effort or activity to change the beliefs of the students. The lectures were handled according to the principles of social constructivism and some authentic responsibilities were given so as to make them work in pair. Students have prepared portfolios to track their improvement. Besides they had the assessment of their peers.

\section{Data Collection Instrument}

"Epistemological beliefs and beliefs about teaching and learning scale" developed by Chai, Teo, and Lee (2009) and adapted later to Turkish by Kıncal, Şahin, and Kartal (2010) is used as a data collection instrument. The scale consists of 30 items to measure attitudes to knowledge and learning and 30 items to measure beliefs about teaching. Some sample items related about data collection instrument are showed in the Table 2 below. The scale is based on a 5-point Likert scale anchored from 1 (Disagree) to 5 (Agree). The validity of this measurement tool was previously conducted and its new value of reliability coefficient is calculated as 0.85 .

Table 2. Sample items used in the study

\begin{tabular}{|c|c|c|c|}
\hline Construct & Factor & Item & Sample item \\
\hline \multirow[t]{3}{*}{ About Learning } & Learning Effort & 3 & $\begin{array}{l}\text { If one tries hard enough, then one } \\
\text { will understand the course material. }\end{array}$ \\
\hline & Learning Processes & 4 & $\begin{array}{l}\text { Wisdom is not knowing the } \\
\text { answers, but knowing how to find } \\
\text { the answers. }\end{array}$ \\
\hline & Innate Ability & 6 & $\begin{array}{l}\text { There isn't much you can do to } \\
\text { make yourself smarter as your } \\
\text { ability is fixed at birth. }\end{array}$ \\
\hline \multirow[t]{2}{*}{$\begin{array}{l}\text { About } \\
\text { Knowledge }\end{array}$} & Certaintry of Knowledge & 4 & $\begin{array}{l}\text { I feel uncomfortable in dealing with } \\
\text { ambiguous situations. }\end{array}$ \\
\hline & $\begin{array}{l}\text { Authority/Expert } \\
\text { Knowledge }\end{array}$ & 3 & $\begin{array}{l}\text { I have no doubts in whatever the } \\
\text { experts say. }\end{array}$ \\
\hline \multirow[t]{2}{*}{$\begin{array}{l}\text { About } \\
\text { Teaching }\end{array}$} & Constructivist Teaching & 9 & $\begin{array}{l}\text { Students should be given many } \\
\text { opportunities to express their ideas. }\end{array}$ \\
\hline & Traditional Teaching & 5 & $\begin{array}{l}\text { Teaching is simply telling, } \\
\text { presenting or explaining the subject } \\
\text { matter. }\end{array}$ \\
\hline
\end{tabular}




\section{Data Collection Process}

Data collection tool was applied to students as a pre-testing at the beginning of the learning process. The post-test application was given to the students as a part of their portfolio that they prepared during their learning processes and they were told to fill it out and bring back. In this way, the data collection tool could be filled more carefully. Consequently, the prospective teachers delivered the tests about the epistemological beliefs with the other outputs in their files to the researchers at the end of the semester.

\section{Statistical Analysis}

As the changes on prospective teachers' beliefs are individually more significant than the group change, the data analysis process given below was followed.

1- With the results of pre and post test scores, the percentage of the values for the bottom dimension of each belief were calculated.

Percentage $=\frac{\text { obtained score }- \text { minimum score }}{\text { Maximum score }- \text { minimum score }} \times 100$

The dominant belief was determined according to high percentage of the related belief.

2- The number of the participants who are in dominant belief in pre and post tests was detected.

3- According to the pre-test and post-test results, the possible changes on each participants about the dominant belief were determined.

4- Changes on beliefs frequencies were calculated on the basis of the general and groups.

5- Binomial $Z$ test was applied in determining the significance of the difference between the groups for rates.

6- Chi-square test was used to determine the significance of the difference between the groups in the rates of triplet and higher.

\section{Findings related to the first sub-problem \\ Findings and Results}

First, a change in beliefs of the prospective teachers about the knowledge; that is, absolute knowledge based on an authority or relative knowledge, was examined in the research. Findings received are as in the followings shown on the Table 3:

Table 3. Values of changes on dominant belief according top pre- and posttests.

\begin{tabular}{lllll}
\hline Diemsions & $\begin{array}{l}\text { Pre-test } \\
f\end{array}$ & $\%$ & Post-test \\
& $f 9$ & $83 \%$ & 110 & $\%$ \\
\hline Relativity of Information & 99 & & & $92 \%$ \\
$\begin{array}{l}\text { Certainity of Information- } \\
\text { authority }\end{array}$ & 20 & $17 \%$ & 9 & $8 \%$ \\
Total & 119 & $100 \%$ & 119 & $100 \%$ \\
\hline
\end{tabular}

Note. $Z=-2.11 ; p<0.05$ (significant) 
The pre-tests results showed that $83 \%$ of the prospective teachers believed relative knowledge and $17 \%$ of the prospective teachers believed absolute knowledge when the findings in the table were analyzed. The pre-test results revealed that the prospective teachers believed relative knowledge too much. According to the post-test results, $92 \%$ of the prospective teachers believed relative knowledge and $8 \%$ of the prospective teachers believed absolute knowledge. The findings indicated that there is a positive change $(83 \% \rightarrow$ $92 \%=+9 \%$ ) in the beliefs of the candidates about relative knowledge, but there is a visible decrease $(17 \% \rightarrow 8 \%=-9 \%)$ in the beliefs about absolute knowledge. Z-test was applied to find statistically the significance level of the distribution in the research. The findings received mean that the differentiation between the rates is meaningful $(Z=-2.11 ; p<0.05)$.

The Table 4 shows how the changes appeared for each candidate in the groups:

Table 4. The changes of beliefs related to information based on groups. (Frequency-percentage)

\begin{tabular}{|c|c|c|c|c|c|c|}
\hline & \multicolumn{2}{|c|}{ General } & \multicolumn{2}{|c|}{ Exp. 1} & \multicolumn{2}{|c|}{ Exp. 2} \\
\hline & $f$ & $\%$ & $f$ & $\%$ & $f$ & $\%$ \\
\hline Relative- Irrelative & 93 & $78 \%$ & 65 & $80 \%$ & $\begin{array}{l}2 \\
8\end{array}$ & $74 \%$ \\
\hline $\begin{array}{l}\text { Relative- Certain } \\
\text { unchangeable }\end{array}$ & 6 & $5 \%$ & 5 & $6 \%$ & 1 & $3 \%$ \\
\hline $\begin{array}{l}\text { Certainity of Information- } \\
\text { Certainity of Information }\end{array}$ & 3 & $3 \%$ & 1 & $1 \%$ & 2 & $5 \%$ \\
\hline $\begin{array}{l}\text { Certainity of Information- } \\
\text { relative }\end{array}$ & 17 & $14 \%$ & 10 & $12 \%$ & 7 & $18 \%$ \\
\hline Total & 119 & $100 \%$ & 81 & $100 \%$ & $\begin{array}{l}3 \\
8\end{array}$ & $\begin{array}{l}100 \\
\%\end{array}$ \\
\hline
\end{tabular}

One possible explanation for the findings in the table is that $78 \%$ of the prospective teachers maintained to believe relative knowledge not only at the beginning of the process but also at the end. However, it was recognized that $5 \%$ of the prospective teachers believed relative knowledge at the beginning of the process whereas they believed absolute knowledge at the end and also 3\% of the candidates believed absolute knowledge both at the beginning and at the end of the process. It was also clear that $14 \%$ of the prospective teachers believed relative knowledge at the end of the process while they believed absolute knowledge too much at the beginning of the process. Sometimes dominant beliefs of the candidates in the research were partially changing during the process and the rate of the candidates believing relative knowledge was more than the rate of others. As a result, learning environment significantly affected the beliefs of the prospective teachers about relative knowledge. 


\section{Findings related to the second sub-problem}

The problem is related to the changes in beliefs of the prospective teachers about learning. The findings received are in the Table 5.

Table 5. Frequencies and percentages of changes of the beliefs related to learning.

\begin{tabular}{lllll}
\hline & Pre-test & \multicolumn{3}{c}{ Post -test } \\
& $\mathbf{f}$ & $\mathbf{\%}$ & $\mathbf{F}$ & $\mathbf{\%}$ \\
\hline Ability & 8 & $7 \%$ & 7 & $6 \%$ \\
Effort & 34 & $28 \%$ & 34 & $28 \%$ \\
Process & 77 & $65 \%$ & 78 & $66 \%$ \\
Total & 119 & $100 \%$ & 119 & $100 \%$ \\
\hline
\end{tabular}

Note. $p=0.964 ; p>0.05$ (not significant)

The findings revealed that $7 \%$ of the candidates believed learning based on ability, experience and $65 \%$ of the candidates also believed learning based on process. The pre-test results indicated that the prospective teachers believed learning much more based on process. In addition to the pre-test results, the post-test results showed that the rate of the candidates believing learning based on ability decreased from $7 \%$ to $6 \%$, the rate of the candidates believing learning based on experience was as the same with the pre-test results and the rate of the candidates believing learning based on process increased from $65 \%$ to $66 \%(+1 \%)$. The findings of the results mean that there was a little decrease in the prospective teachers' beliefs about learning based on ability, the beliefs about learning based on experience were at the same rate and there was a little increase in beliefs about learning based on process. According to Chi-Squared test, the changes in the pre and post-tests are not statistically meaningful.

The changes in beliefs of the prospective teachers are individually shown in the Table 6.

Table 6. Frequencies and percentages of changes of beliefs related to learning.

\begin{tabular}{lllllll}
\hline & General & \multicolumn{3}{c}{ I. Group } & \multicolumn{3}{c}{ II. Group } \\
& $\mathrm{f}$ & $\%$ & $\mathrm{~F}$ & $\%$ & $\mathrm{f}$ & $\%$ \\
\hline Ability- Ability & 3 & $3 \%$ & 2 & $2 \%$ & 1 & $3 \%$ \\
Ability -Effort & 0 & $0 \%$ & 0 & $0 \%$ & 0 & $0 \%$ \\
Ability - Process & 5 & $4 \%$ & 5 & $6 \%$ & 0 & $0 \%$ \\
Effort - Effort & 16 & $13 \%$ & 10 & $12 \%$ & 6 & $16 \%$ \\
Effort - Ability & 2 & $2 \%$ & 1 & $1 \%$ & 1 & $3 \%$ \\
Effort - Process & 16 & $13 \%$ & 9 & $11 \%$ & 7 & $18 \%$ \\
Process - Process & 57 & $48 \%$ & 37 & $46 \%$ & 20 & $53 \%$ \\
Process - Effort & 18 & $15 \%$ & 15 & $19 \%$ & 3 & $8 \%$ \\
Process - Ability & 2 & $2 \%$ & 2 & $2 \%$ & 0 & $0 \%$ \\
Total & $\mathbf{1 1 9}$ & $\mathbf{1 0 0} \%$ & $\mathbf{8 1}$ & $\mathbf{1 0 0} \%$ & $\mathbf{3 8}$ & $\mathbf{1 0 0} \%$ \\
\hline
\end{tabular}


In the findings as shown in the tables, it is observed that the percentage of those whose beliefs are kept on that learning depends on the gift is $3 \%$, that there is not anyone those who start to believe in that learning depends on the effort while believing in that learning depends on the ability $(0 \%)$, that the percentage of those who start to believe in that learning depends on the process while believing in that learning depends on the ability is $4 \%$. The percentage of those who kept their beliefs on that learning depends on the effort is $13 \%$. It is observed that the percentage of those who start to believe in that learning depends on the ability while believing in that learning depends on the effort is $2 \%$ and the percentage of those who start to believe in that learning depends on the process while believing in that learning depends on the effort is $13 \%$. In the table, it is clear that at the end of the process, the percentage of those whose beliefs remain the same as it was in the beginning of the process is $48 \%$, and the percentage of those who start to believe in that learning depends on the effort while believing in that learning depends in process is $15 \%$, and the percentage of those who changed their beliefs from process to ability is $2 \%$. The difference between the group 1 and the group 2 is observed to be close to each other for each dimension.

According to the findings, provided in the Table 6 , it can be concluded that social constructivist learning setting changes the dominant beliefs of prospective teachers' partially and that they can believe in that learning depends on mostly process and effort.

\section{Findings related to the third sub-problem}

On which directions occur the changes in the beliefs of prospective teachers are given in the Table 7.

Table 7. Frequencies and percentages of the changes of beliefs related to teaching.

\begin{tabular}{lllll}
\hline & Pre-test & \multicolumn{3}{c}{ Post-test } \\
& $\mathrm{f}$ & $\%$ & $\mathrm{~F}$ & $\%$ \\
\hline Traditional & 7 & $6 \%$ & 2 & $2 \%$ \\
Constructivist & 112 & $94 \%$ & 117 & $98 \%$ \\
Total & 119 & 100 & 119 & 100 \\
\hline
\end{tabular}

Note. $Z=1.58 ; p>0.05$ (not significant)

The pre-test results reveal that the rate of the candidates, believing that learning should be in a classical way was $6 \%$ and the rate of the post-test results was $2 \%$. The findings indicates that the candidates believed that learning should not be in a classical way at the end of process, but the beliefs about classical learning decreased in $4 \%$. The pre-test results showed that most of the prospective teachers ( $94 \%$ ) believed that teaching should be constructed and at the end of the process the beliefs of constructivist teaching increased in $4 \%$ (98\%). Z-test was applied to find out whether the increase is meaningful or not. At the end of test analysis, the results indicated that the differences between 
the rates are not meaningful. The learning approach that was applied during the research supported the beliefs about constructivist teaching.

The findings of analyses conducted to determine on which directions occur the change of the beliefs in terms of groups in the basis of individuals are given below in the Table 8.

Table 8. Frequencies and percentages of the changes of beliefs related to teaching of individuals in groups.

\begin{tabular}{lllllll}
\hline & General & \multicolumn{3}{c}{ I. Group } & \multicolumn{2}{c}{ II. Group } \\
& $\mathrm{f}$ & $\%$ & $\mathrm{~F}$ & $\%$ & $\mathrm{f}$ & $\%$ \\
\hline Constructivist- Constructivist & 110 & $92 \%$ & 73 & $90 \%$ & 37 & $97 \%$ \\
Constructivist -Traditional & 2 & $2 \%$ & 1 & $1 \%$ & 1 & $3 \%$ \\
Traditional - Traditional & 0 & $0 \%$ & 0 & $0 \%$ & 0 & $0 \%$ \\
Traditional - Constructivist & 7 & $6 \%$ & 7 & $9 \%$ & 0 & $0 \%$ \\
Total & $\mathbf{1 1 9}$ & $\mathbf{1 0 0} \%$ & $\mathbf{8 1}$ & $\mathbf{1 0 0} \%$ & $\mathbf{3 8}$ & $\mathbf{1 0 0 \%}$ \\
\hline
\end{tabular}

It was recognized that the rate of the candidates believing constructivist approach who did not change their beliefs at the beginning and also at the end of the process was $92 \%$.The rate of the candidates who changed classically their beliefs about constructivist approach was $2 \%$ at the end of the process while they had strong beliefs in the same approach at the beginning of the process. Moreover, the rate of candidates who changed their current beliefs into constructivist approach at the end of the process was $6 \%$ whereas at the beginning of the process they had strong beliefs in classical approach. The findings in the research show that the applied approach of the research did not change the prospective teachers' own approach; on the contrary, it supported to remain basically the same.

\section{Discussion}

In the study the finding showed that there is a visible positive change in the beliefs about relative knowledge whereas a visible decrease in the beliefs about absolute knowledge of the candidates. The findings revealed that $7 \%$ of the candidates believed learning based on ability, experience and $65 \%$ of the candidates also believed learning based on process. Discussion of the research is related to the significance of the epistemological belief changes in growing teachers and the changes at subsection of the epistemological beliefs.

Generally, the findings related to the epistemological beliefs in many academic researches show that there is a change (Joanne \& Brownlee, 2001; Buehl \& Five, 2009) in spite of being difficult to state such a change in some researches (Posner, Strike, Hewson \& Gertzog, 1982; Ryder, 1994; Wilson, 1990). Epistemological beliefs which is changeable during education is fundamental for the teacher training. Today, it is more and more important to grow the teachers who will be able to design a valid classroom environment in forms of teaching programs as the teachers' classroom activities affected by the previous 
education environments are considered (Aldrich \& Thomas, 2005; Chai et al., 2009).

The other fundamental point is that the prospective teachers' current beliefs to support a life-long learning are not well-qualified. It is also visible for the teachers to maintain their own professional development due to learn new approaches and to use these approaches effectively in their own classrooms (Borko, 2004). If the teachers do not believe the validity of the life-long learning, they will have a burnout syndrome on early days of their jobs.

A great number of the teachers candidates believed absolute knowledge much more than relative knowledge when the beliefs of how knowledge -a subsection of epistemological beliefs- exists, was argued. Similarly, in Chan's (2003) research, the students believed the existence of unchangeable knowledge. Owing to the fact that there are active cultural differences in epistemological beliefs, there appears a similar situation. In different sample groups, beliefs over great numbers related to unchangeable knowledge were seen (Topçu, 2011).One of the highlights in that part, there are transition of the knowledge from relativity to absolute.

The beliefs that support the constructivist approach in the beliefs about learning based on ability, experience and process were mostly observed. There are researches parallel with the research findings.

The majority in the group agrees that teaching should be constructed in the beliefs of the students related to constructed or classical teaching. In their researches, Meral and Çoluk (2009) and Terzi (2005) found that most of the students believed classical teaching. (Chan , Tan \& Khoo, 2007; Otting et al.,2010 ).In their study, similar to working group, most of the prospective teachers believed constructivist teaching. In the research, there is a transition from classical approach to constructivist approach and there is a transition from constructivist to classical approach at least when the students were individually investigated.

The research was generally evaluated by remaining the beliefs of the prospective teachers related to relative knowledge same indicates that teaching environment supports the candidates to maintain their own beliefs. On the other hand, teaching environments change the beliefs of the candidates.

\section{References}

Aksan, N. (2006). Üniversite Öğrencilerinin Epistemolojik İnançları ile Problem Çözme Becerileri Arasındaki İlişki. Yüksek Lisans Tezi, Çanakkale Onsekiz Mart Üniversitesi Sosyal Bilimler Enstitüsü Eğitim Bilimleri Anabilim Dalı, Çanakkale.

Aldrich, J.E., \& Thomas, K.R. (2005). Evaluating constructivist beliefs of teacher candidates. Journal of Early Childhood Teacher Education, 25(4), 339-347.

Aypay, A. (2011). The adaptation of the teaching-learning conceptions questionnaire and its relationships with epistemological beliefs. Educational Sciences: Theory and Practice, 11(1), 21-29.

Borko, H. (2004). Professional development and teacher learning: Mapping the terrain. Educational researcher, 33(8), 3-15. 
Brooks, J.G. (2002). Schooling for life: Reclaiming the essence of learning. Alexandria, VA: ASCD

Brownlee, J. (2001). Epistemological beliefs in pre-service teacher education students. Higher Education Research and Development, 20(3), 281-291.

Brownlee, J. (2003). Changes in primary school teachers' beliefs about knowing: A longitudinal study. Asia-Pacific Journal of Teacher Education, 31(1), 8798.

Brownlee, J., Purdie, N., \& Boulton-Lewis, G. (2001). Changing epistemological beliefs in pre-service teacher education students. Teaching in Higher Education, 6(2), 247-268. doi: 10.1080/13562510120045221

Buehl, M.M. (2003). At the Crossroads of Epistemology and Motivation: Modeling the Relations between Students' Domain-Specific Epistemological Beliefs, Achievement Motivation, and Task Performance. (Doctor of Philosophy), University of Maryland.

Buehl, M.M., \& Fives, H. (2009). Exploring teachers' beliefs about teaching knowledge: where does it come from? Does it change? The Journal of Experimental Education, 77(4), 367-408.

Chai, C.S., Teo, T., \& Lee, C.B. (2009). The change in epistemological beliefs and beliefs about teaching and learning: a study among pre-service teachers. Asia-Pacific Journal of Teacher Education, 37(4), 351-362.

Chan, K. (2004). Preservice Teachers' Epistemological beliefs and conceptions about teaching and learning: Cultural implications for research in teacher education. Australian Journal of Teacher Education, 29(1), 1.

Chan, K. W. (2003). Hong Kong teacher education students' epistemological beliefs and approaches to learning. Research in Education 69(1), 36-50.

Chan, K. W., \& Elliott, R.G. (2002). Exploratory study of Hong Kong teacher education students' epistemological beliefs: Cultural perspectives and implications on beliefs research. Contemporary Educational Psychology, 2オ(3), 392-414.

Chan, K. W., Tan, J., \& Khoo, A. (2007). Preservice teachers' conceptions about teaching and learning: A closer look at Singapore cultural context. Asia-Pacific Journal of Teacher Education, 35(2), 181-195.

Chan, K.W., \& Elliott, R.G. (2000). Exploratory study of epistemological beliefs of Hong Kong teacher education students: Resolving conceptual and empirical issues. Asia-Pacific Journal of Teacher Education, 28(3), 225-234.

Chan, K.W., \& Elliott, R.G. (2004). Relational analysis of personal epistemology and conceptions about teaching and learning. Teaching and Teacher Education, 20(8), 817-831.

Cheng, M.M.H., Chan, K.W., Tang, S.Y.F., \& Cheng, A.Y.N. (2009). Pre-service teacher education students' epistemological beliefs and their conceptions of teaching. Teaching and Teacher Education, 25(2), 319-327.

Clarebout, G., Elen, J., Luyten, L., \& Bamps, H. (2001). Assessing epistemological beliefs: Schommer's questionnaire revisited. Educational Research and Evaluation, $7(1), 53-77$.

Deryakulu, D. (2004). Epistemolojik inançlar. In Y. Kuzgun \& D. Deryakulu (Eds.), Eğitimde bireysel farklılıklar (pp. 259-288). Ankara: Nobel Yayınevi. 
Entwistle, N., Skinner, D., Entwistle, D., \& Orr, S. (2000). Conceptions and beliefs about "good teaching": An integration of contrasting research areas. Higher Education Research and Development, 19(1), 5-26.

Entwistle, N.J., \& Peterson, E.R. (2004). Conceptions of learning and knowledge in higher education: Relationships with study behaviour and influences of learning environments. International Journal of Educational Research, 41(6), 407-428.

Hofer, B.K. (2002). Personal epistemology as a Psychological and educational construct: An Introduction. In B. K. Hofer \& P. R. Pintrich (Eds.), Personal epistemology: The psychology of beliefs about knowledge and knowing (pp. 3-14): Lawrence Erlbaum Assoc Inc.

Hofer, B.K., \& Pintrich, P.R. (1997). The development of epistemological theories: Beliefs about knowledge and knowing and their relation to learning. Review of Educational Research, 671), 88-140.

Kıncal, R., Şahin, Ç. , \& Kartal, O.Y. (2010). Determining the change of preservice teachers' epistemological beliefs and beliefs on teaching and learning. Paper presented at the I. Curriculum and Instruction Congress, Balıkesir, Türkiye.

Lawrence, C.L. (1992). Preservice teachers' development of pedagogical understandings and epistemological frameworks. Paper presented at the Annual Meeting of the Educational Research Association, San Francisco.

Levin, T., \& Wadmany, R. (2005). Changes in educational beliefs and classroom practices of teachers and students in rich technology-based classrooms [1]. Technology, Pedagogy and Education, Vol. 14, No. 3, 2005, 14(3), 281-307.

Lodewyk, K.R. (2007). Relations among epistemological beliefs, academic achievement, and task performance in secondary school students. Educational psychology, 27(3), 307-327.

Otting, H., Zwaal, W., Tempelaar, D., \& Gijselaers, W. (2010). The structural relationship between students' epistemological beliefs and conceptions of teaching and learning. Studies in Higher Education, 35(7), 741-760.

Pajares, M.F. (1992). Teachers' beliefs and educational research: Cleaning up a messy construct. Review of Educational Research, 62(3), 307-332.

Perry, W. (1981). Cognitive and ethical growth: The making of meaning. In A. Chickering (Ed.), The modern American college (pp. 76-116). San Francisco: Jossey-Bass.

Perry, W.G. (1970). Forms of intellectual and ethical development. New York: Holt, Rinehart \& Winston.

Posner, G.J., Strike, K.A., Hewson, P.W., \& Gertzog, W.A. (1982). Accommodation of a scientific conception: Toward a theory of conceptual change. Science education, 66(2), 211-227.

Ravindran, B., Greene, B.A., \& Debacker, T.K. (2005). Predicting preservice teachers' cognitive engagement with goals and epistemological beliefs. The Journal of Educational Research, 98(4), 222-233.

Renne, C.G. (1992). Elementary School Teachers' Views of Knowledge Pertaining to Mathematics. Paper presented at the Annual Meeting of the American Research Association, San Francisco. 
Richardson, V., Anders, P., Tidwell, D., \& Lloyd, C. (1991). The relationship between teachers' beliefs and practices in reading comprehension instruction. American Educational Research Journal, 28(3), 559-586.

Ryder, P.M. (1994). Giving or Taking Authority: Exploring the Ideologies of Collaborative Learning. Paper presented at the 45th Annual Meeting of the Conference on College Composition and Communication, Nashville, TN.

Schommer, M. (1990). Effects of beliefs about the nature of knowledge on comprehension. Journal of educational psychology, 82(3), 498.

Schommer, M., \& Dunnell, P.A. (1997). Epistemological beliefs of gifted high school students. Roeper Review, 19(3), 153-156.

Schommer-Aikins, M., Mau, W.C., Brookhart, S., \& Hutter, R. (2000). Understanding middle students' beliefs about knowledge and learning using a multidimensional paradigm. The Journal of Educational Research, 94(2), 120-127.

Schreiber, J.B., \& Shinn, D. (2003). Epistemological beliefs of community college students and their learning processes. Community College Journal of Research \&Practice, 278), 699-709.

Shaver, J.P. (1992). Epistemology and the Education of Social Science Teachers. Paper presented at the International Conference on Subject-specific Teaching Methods and Teacher Education, Santiago de Compostela, Spain.

Smith, M.V., \& Haack, P. (2000). The long view of lifelong learning. Music Educators Journal, 87(3), 28-33.

Tolhurst, D. (2007). The influence of learning environments on students' epistemological beliefs and learning outcomes. Teaching in Higher Education, 12(2), 219-233.

Topcu, M.S. (2011). Turkish elementary student teachers' epistemological beliefs and moral reasoning. European Journal of Teacher Education, 34(1), 99125.

Trigwell, K., Prosser, M., \& Waterhouse, F. (1999). Relations between teachers' approaches to teaching and students' approaches to learning. Higher Education, 37(1), 57-70.

Tumkaya, S. (2012). The investigation of the epistemological beliefs of university students according to gender, grade, fields of study, academic success and their learning styles. Educational Sciences: Theory and Practice, 12(1), 88-95.

Wilson, S.M. (1990). The Secret Garden of Teacher Education. The Phi Delta Kappan, 72(3), 204-209.

Young, A.W. (2000). Wondrous strange: The neuropsychology of abnormal beliefs. Mind \& Language, 15(1), 47-73.

Zhu, C., Valcke, M., \& Schellens, T. (2008). The relationship between epistemological beliefs, learning conceptions, and approaches to study: a cross-cultural structural model? Asia Pacific Journal of Education, 28(4), 411-423. 